years earlier, suggesting increased fatness between the two populations.

Our charts were derived from cross sectional data.

Our reason for correlating BMI with body fat estimates from skinfold thickness and bioelectrical impedance was to show the relationship between three measures of fatness estimation that are currently in common use.

1 Cole TJ, Freeman JV, Preece MA. Body mass index reference curves for the UK, 1990. Arch Dis Child 1995 (in press)

2 Rolland-Cachera MF, Cole T, Sempe M, Tichet $\mathrm{J}$, Rossignol C, Charraud A. Body mass index variations: centiles from birth to 87 years. Eur $\mathcal{F}$ Clin Nutr 1991; 45: 13-21.

\section{Trends in breast feeding in New Zealand}

EDITOR,-Breast feeding is the best method of feeding young infants with health benefits for them and their mothers. ${ }^{12}$ Like other developed countries New Zealand suffered a postwar decline in its breast feeding rates that reached a nadir in the late 1960 s. The reasons were multifactorial. They included changes in the status of women, with more women working outside the home; increased mobility with loss of contact with extended families and older women who could offer breast feeding support; a belief in the superiority of technology and science; and advertising of infant formulas as being superior to breast milk.

The Royal New Zealand Plunket Society was established in 1907 and provides well child care to children under 5 years old in New Zealand. Plunket nurses (equivalent to health visitors in the UK) now see over $90 \%$ of infants under 1 year of age, usually from two to three weeks postpartum. Data collected since 1946 on breast feeding rates at the first contact with the Plunket nurse and the percentage of infants who see the Plunket nurse are shown in the figure. The data do not differentiate between exclusive or partial breast feeding.

The breast feeding rates in New Zealand and Great Britain ${ }^{4} 15$ to 20 years age were approximately the same. However, since then New Zealand's breast feeding rate has risen steadily and now around $84 \%$ of infants are being breast fed when seen by Plunket nurses as 2 to 3 weeks of age. This compares with a recent study of a cohort of $7 \%$ of New Zealand infants born in 1990-1 in which $94 \%$

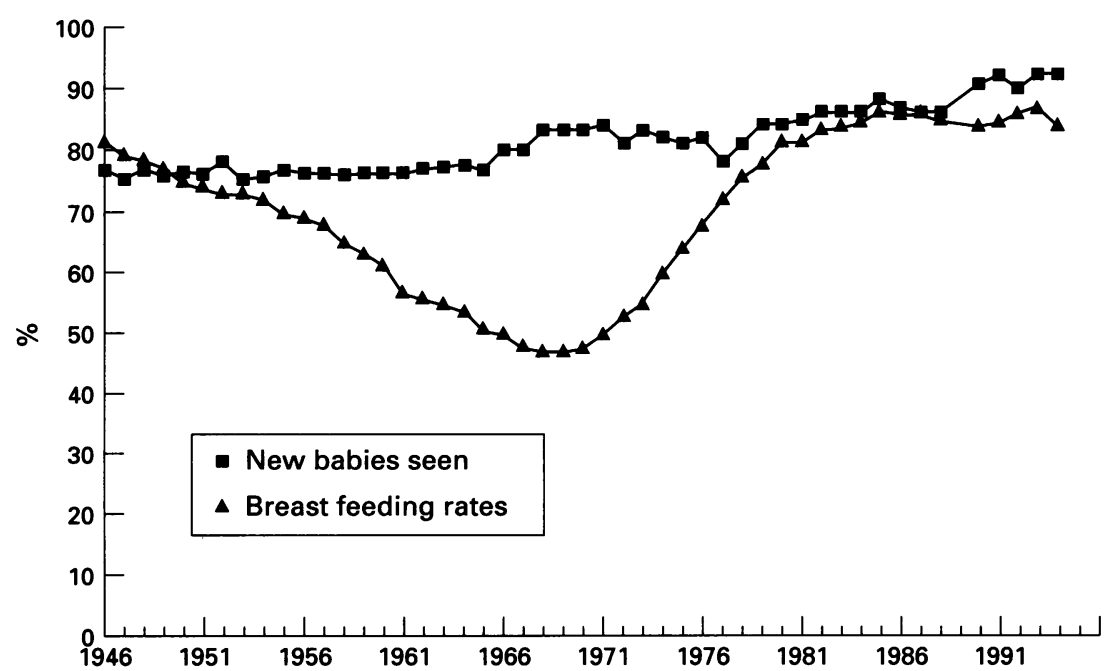

Percentage of new babies seen and breast feeding rates at first contact with the Plunket Society (1946-94); first contact is between birth and 3 weeks of age. of them were breast fed at birth (Plunket

The reasons for the increase in breast feeding rates, like the reasons for the decline, are probably multifactorial. These may include home visiting by Plunket nurses up to six to nine weeks postpartum; Plunket family centres, which are free day centres staffed by Plunket nurses who are lactation consultant where mothers with breast feeding problems can go; increased awareness of the benefits of and promotion of breast feeding, 'tots and toddlers' education programmes in schools for 13 and 14 year olds.

The increase in breast feeding rates is similar to that found by Hofvander and Sjolin in Sweden where the breast feeding rates rose from an all time low of $31 \%$ in 1972 to $62 \%$ in 1976-7 by using an information and education campaign about the superiority and value of breast feeding. ${ }^{5}$ The overall rate of mothers breast feeding their babies at birth in Great Britain has stayed around 63\% since $1975^{4}$ and in some areas initial breast feeding rates are as low as $8 \% .^{6}$ These data show that the decline in breast feeding can be reversed and the breast feeding rate markedly improved in little over a decade.

CHARIES ESSEX PAUL SMAIE Royal New Zealand Plunket Society (Correspondence to: Dr Essex 30 Hallewell Road

Edgbaston, Birmingham B16 OLR

1 Cunningham AS, Jelliffe DB, Jelliffe EF. Breastfeeding and health in the 1980s: a global epi659-66.

2 Howie PW, Forsyth JS, Ogston SA, et al. Protective effects of breast-feeding against infection. BMF 1990; 300: 11-6.

3 Dwyer J, Mayer J. The demise of breast feeding sales, sloth or society? Unicef. Priorities in child nutrition. Vol II. New York. Unicef, 1975.

4 Office of Population Censuses and Surveys. Infant feeding 1990. London: HMSO, 1992.

Hofvander Y, Sjolin S. Breast feeding and recent information activities in Sweden. Acta Paediat Scand 1979; 275 (suppl): 122-5.

6 Ferguson A, Tappin DM, Girdwood RWA, et al. Breast feeding in Scotland. BMf 1994; 308: $824-5$.

Premenarchal endometrial shedding revealed by peritoneal dialysis

EDITOR,-In our centre three female patients have reached menarche while undergoing Society, unpublished data).
Peritoneal and vaginal bleeding in three pubertal girls on peritoneal dialysis

\begin{tabular}{llll}
\hline \multirow{2}{*}{$\begin{array}{l}\text { Age } \\
\text { (years) }\end{array}$} & \begin{tabular}{l} 
Bleeding \\
\cline { 2 - 4 } $\begin{array}{l}\text { Peritoneal } \\
\text { (days) }\end{array}$
\end{tabular} & $\begin{array}{l}\text { Vaginal } \\
\text { (days) }\end{array}$ & $\begin{array}{c}\text { Cycle } \\
\text { length } \\
\text { (days) }\end{array}$ \\
\hline $14 \cdot 1$ & 1.5 & 0 & 22 \\
& $0 \cdot 75$ & 0 & 30 \\
& 1.5 & 0 & 27 \\
& $3 \cdot 0$ & 0 & 60 \\
13.0 & $7 \cdot 25$ & $7 \cdot 0$ & - \\
& $3 \cdot 5$ & 0 & 41 \\
& $2 \cdot 0$ & 0 & 37 \\
& $2 \cdot 0$ & $0 \cdot 5$ & 41 \\
15.3 & $5 \cdot 0$ & 3.0 & 27 \\
& $0 \cdot 15$ & 0 & - \\
& $1 \cdot 0$ & 0 & 38 \\
& $0 \cdot 25$ & 0 & 32 \\
& $0 \cdot 25$ & 0 & - \\
\hline
\end{tabular}

peritoneal dialysis. All have shown cyclical blood staining of peritoneal dialysis fluid which preceded any vaginal bleeding (table) Microscopy of the stained dialysis fluid showed 2000-4400 red blood cells/ $\mu$ l and $0-20$ white blood cells $/ \mu l$ and cultures of dialysis fluid showed no growth. The first two patients shown in the table went on to have regular menses with peritoneal fluid staining The last patient underwent renal transplantation with removal of dialysis catheter and regular vaginal bleeding began six months later.

This observation is consistent with the finding that retrograde menstruation is almost universal in adult women ${ }^{12}$ and well recognised among adult women using peritoneal dialysis. ${ }^{3}$ Other premenarche cyclical changes or 'dawn phenomena' have been described and found important in the management of adolescent young women with other chronic conditions. ${ }^{4}$ Pubertal young women using peritoneal dialysis should be made aware of this phenomenon to avoid blood stained dialysis bags causing unnecessary anxiety and alarm for the patient and her family and unnecessary investigations or treatment by medical staff. Indeed, as this phenomenon is universal in our adolescent female population, young women should expect cyclical blood staining of their peritoneal dialysis fluid in the months before their periods begin.

The timing of this cyclical blood loss suggests it is endometrial in origin. The presence of blood in the peritoneal fluid for several cycles before any vaginal bleeding is seen may indicate that the cervical changes known to occur in late puberty are necessary to allow free blood flow into the vagina. ${ }^{5}$ This observation is consistent with endometrial development occurring before cervical maturation. In one case, a cycle of vaginal bleeding with peritoneal fluid staining was followed by a brief episode of peritoneal fluid staining without concurrent vaginal bleeding. This is consistent with retrograde menstruation occurring in preference to vaginal bleeding. Some young women approaching the menarche have monthly lower abdominal pain which, according to common folklore, is a sign that periods will soon begin. Such monthly pains may be caused by intraperitoneal blood from cyclical endometria shedding.

Cyclical phenomena occurring before the menarche warrant further investigation which might include serial ultrasound of the ovaries and serial sex hormone and gonadotrophin levels. Adolescent women undergoing peritoneal dialysis have provided a window into these normal pubertal phenomena. 